\title{
Protecting Dignity: Analysis of the Literary Representation of Legal Issues Related to Dementia
}

\begin{abstract}
When he was alone, José Arcadio Buendía consoled himself with the dream of the infinite rooms. He dreamed that he was getting out of bed, opening the door and going into an identical room [...]. As in a gallery of parallel mirrors, until Prudencio Aguilar would touch him on the shoulder. Then he would go back from room to room, walking in reverse, going back over his trail, and he would find Prudencio Aguilar in the room of reality. But one night, two weeks after they took him to his bed, Prudencio Aguilar touched his shoulder in an intermediate room and he stayed there forever, thinking that it was the real room.
\end{abstract}

(Márquez, 2012, 143)

The newest edition of Diagnostic and Statistical Manual of Mental Disorders (DSM-5) discusses dementia under the label of Neurocognitive Disorders. The diagnostic criteria for mild NCD include: (A) Evidence of modest cognitive decline from a previous level of performance in one or more cognitive domains (complex attention, executive function, learning and memory, language, perceptual motor, or social cognition) [...]. (B) The cognitive deficits do not interfere with capacity for independence in everyday activities (i.e., complex instrumental activities of daily living such as paying bills or managing medications are preserved, but greater effort, compensatory strategies, or accommodation may be required (Simpson, 2014, 160). In laypeople terms, its most common symptom is memory dysfunction, loss of memories and the following disintegration of personality. As David Shenk (2003) puts it: "[...] as the disease relentlessly progresses toward the final dimming of the sufferer, it forces us to experience death in a way it is rarely otherwise experienced. What is usually a quick flicker we see in super slow motion, over years." Dementia is one of the biggest challenges aging societies are facing in the 21 st century. Not a stand-alone disease, but a clinical syndrome that can occur in many diseases, most frequently caused by Alzheimer's.

The number of patients with dementia in Hungary is estimated at 200,000 (Vajda, 2020). Nevertheless, the awareness of laymen and professionals about the syndrome is still low. Related to this is the fact that most patients are not diagnosed in the early stages of the disease and do not receive specific treatment that could slow their deterioration. However, a more complex issue than a lack of knowledge is a true understanding of dementia, in which stories and literature can help us. Indeed, 
dementia has a wide literature, for a review of the Alzheimer's literature see Block (2014).

Dementia is handled by the legal system through the concept of legal capacity. For Hungarian law, dementia is a condition with a partial or even total incapacity for sound decision-making in the advanced and late stages of the disease. As far as legal "treatment" is concerned, preserving the dignity of patients is a key issue. As dementia is usually long-lasting, Act $V$ of 2013 on the Civil Code (Civil Code) $\S 2: 39$ which establishes preliminary legal declaration could be of paramount importance in case of early diagnosis. In addition, patients with dementia could typically walk through the relevant institutions of the Civil Code from the supported decisionmaking to the guardianship which partially and then completely restricts the ability to act. As the disease unfolds, respecting the will and preserving the dignity of the sufferer becomes more and more difficult. This is partly a regulatory issue, but largely depends on the functioning of the social care system. However, the proper functioning of this system must be secured by legal tools as the effective control over the activities of carers and guardians is also based on good regulation.

\section{Method}

There are several branches of law and literature research. The most basic division distinguishes between law in literature and law as literature approaches. The former deals with the analysis of the literary representation of legal institutions, while the latter uses the tools and insights of literary studies to understand legal texts and discourses. In his summarizing study, H. Szilágyi $(2010,5)$ states that the focus of the former approach is on the relationship between law and justice, and the aim of the analysis of literary reflections is often to critique black-letter law and to formulate moral lessons.

Although the short analysis presented in this paper can be classified as a part of the law in literature studies, its aim is not specifically to critique the relevant legal institutions (supported decision-making, guardianship, preliminary legal declaration) handling the decline in legal capacity. Dementia has become a widespread disease in 21 st century societies, yet in a sense it remains a mysterious, unapproachable condition. With the loss of memories, an essential element of identity is damaged, so dementia raises not only health, social, or even legal issues, but leads directly to the philosophical problem of an individual's self-identity. It is also less and less comprehensible to family members and the patient's wider environment what the person is going through as the disease progresses. Lawyers, legislators, and law enforcers alike, generally lack the proper expertise on this condition, but the lack of real understanding is an even more fundamental problem. The basic thesis of this study is that literary narratives can help understand dementia. Through these stories, legal professionals, or even law students, can learn about this condition which is a preliminary condition of good legislation and legal decisions alike.

This kind of cognition is especially valuable because it brings the problem closer than studying the scientific literature on the disease, it brings real, emotional involvement and experience. On the other hand, as a reader, we can keep some distance, by reading these fictitious stories we have the opportunity to reflect more 
emphatically on this particular area of human experience, which, once it becomes the story of our own family history, we no longer can contemplate in such a way.

These, of course, are not radically new insights. In connection with minority experiences, from time to time emerges a need to create a language for telling and narrating them, to have words for these experiences. These stories make the reality and social experience of minority members become more accessible to others. This insight is very important for feminist social sciences, such as feminist legal theory, but Critical Race Theory scholars also consider it of paramount importance and use the tools and methods of legal storytelling. The legal theories of minority consciousness usually rely more heavily on qualitative approaches then traditional legal and sociological research, placing much greater emphasis on telling stories and "counter stories" (Delgado, 1989). They need this because they are trying to show an alternative reading of reality, through the experiences of those who belong to a minority group. As Tamás Nagy put it describing the difference between European and American narrative legal theory: "The main purpose of the American school [of law and literature studies] is to give voice to minority groups 'silenced' by history, expressing the viewpoints and interests of traditionally marginalized, oppressed social groups". This school seeks to describe the oppressive nature of translating social conflicts to the "neutral" legal language and wants to enable formulating other narratives about them (Nagy, 2015, 115).

\section{RESULTS}

The theme of dementia is slowly finding its way into the mainstream, or at least to works that reach the public. In 2020, Florian Zeller's drama The Father was shown, an adaptation of a play. Anthony Hopkins, who plays the title role of a father with Alzheimer's disease in the movie, won an Oscar for his portrayal, which also gave great publicity the movie and thus the theme depicted in it. However, many literary works deal with the subject of dementia (e.g. Bernlef, 1984; Bayley, 1999; Franzen, 2001; DeBaggio, 2002; Genova, 2007; Harvey, 2010; Cabré, 2011; Keaton, 2011; Enger, 2013; Thomas, 2014; Kawaguchi, 2019).

One of the central questions in these literary works is the relationship between identity and memories, the question of the disintegration of the personality, or even the appearance of some sort of essential personality that remains after the loss of the memories of a life. In addition, the authors are usually concerned with the topic of the family: the history of the parents and its impacts on their children, the relationship, conflicts, alienation between parents and children, the recollection of decisive decisions that may have dissolved in their daily lives back when they happened, but the struggle for memories makes their significance clearer, corrections, possibility of reconciliation, dissolution.

As for the legal issues related to dementia, they usually do not play a prominent role in these stories. The right to diagnosis, the right to self-determination at an early stage, and the right to appropriate treatment and care as the disease progresses, and the problem of alternate decision-making all affect the fundamental right to dignity. Legal language and evaluation do not usually appear in works dealing with dementia, nor do the actors of the legal system (guardianship authority, court, 
guardian, or supporter). Dementia affects fundamental layers of personality and family relationships that seem to almost repel legal evaluation, making representation of legal threads in literary narratives meaningless, irrelevant. This shortcoming is instructive, it shows well how distant and ineffective the current legal solutions are in the everyday interpretation of the disease, whether for patients or for family members. However, this does not mean that the legal framework regarding legal capacity and the institutions of the social care system governed by the law do not have a role in resolving the problems of self-determination of patients with dementia. Moreover, a better understanding of the situation of patients and their families is key to developing better legal solutions reflecting their needs.

In the following I examine how the topic of (1) preparation after diagnosis and (2) the theme of guardianship, care, and preservation of dignity appears in some literary works dealing with dementia.

\subsection{Diagnosis and preparation}

In some works, the author presents dementia as a process in which the patient is "lost" from the very beginning, even at an early stage, their previous independence and agency immediately disintegrates, dissolves into the role of the patient, they are completely occupied by the frightening process threatening the basis of their existence. The concepts of education, up-to-date, readily available knowledge, early diagnosis, adequate health information and care do not appear articulately, although when we reflect on this, its lack is a very defining feature in the works. The protagonists' rights to receive clear answers to their questions in the early stages of their illness are violated. This on a personal level entails uncertainty and fear, which is a prominent element in these stories. Reflecting on the legal consequences, it is not difficult to see that the patient's right to self-determination is also violated. The naturalness of this is well illustrated by the fact that in many of these otherwise sensitive, complex works depicting the phenomenon of dementia, it does not provoke any criticism from any of the characters.

A good example of this is the protagonist of Bernlef's work, Marteen Klein. Marteen lives in a closed and comfortable microworld with his wife, Vera, and their dog. The image of their life in the work is both monotonous and intimate, with few characters, the days are spent in a certain warm uniformity. Marteen is completely preoccupied from the first moment of the novel with the fact that this safe environment around him is confused, the days and hours lose their linearity, the episodes of oblivion interrupt the peaceful flow of time. In parallel, the past is becoming more and more alive for Marteen. However, there is no question of diagnosis, confrontation, disposition, preliminary declarations of law, at least for the protagonist, these issues do not seem to exist. These questions in Out of Mind are Vera's questions, her problems. Vera faces the diagnosis, she is trying to find a solution, looking for a nurse for her husband.

Another example of this approach is Cecilie Enger's work, My Mother's Gifts: "It had been six months since Mom got into my sister's car, deeply confused, without asking where they were going. Anne Johanne held her hand the whole time as she set off on the gravel road and rolled out the gate and drove to the nursing home where 
a place was provided for Mom." (Enger, 2013). The author describes the reaction of the narrator's mother in the early stages of the disease as follows: "When Alzheimer intervened, Mother's despair became unsheathed, she began to speak desperately to keep the frightening and ever-slipping world in place. And she kept writing, scribbled notes, letters, lists, dates. The sentences became shorter and shorter, the connections broke, significant episodes jumped through, everything was interrupted, and the meaning disappeared." (Enger, 2013).

Facing the diagnosis and provided with proper information, the characters' reaction changes: they try to find a solution. The protagonist of Still Alice, when she finds out she has Alzheimer's, writes herself a letter beginning with five questions to her future self ("What month is it? [...] How many children do you have?"). In the letter Alice informs herself that if she cannot answer these, she no longer lives the life she wants. The letter then gives detailed instructions for suicide. However, Alice, the recipient, can no longer follow the instructions, even though she intends to. However, the final lesson of the novel is that Alice, who was diagnosed, did not judge her situation correctly, because as the disease progresses, memories are lost, the complexity of the personality disappears, but in the end some kind of core identity remains, and the foundation of dignity is preserved, Alice remains Alice (Genova, 2007).

The subject of the letter to the future also appears in the work of Kawaguchi (2019). The story of Before the Coffee Gets Cold is built around a specific, limited form of time travel. In a certain chair in a Tokyo cafe, you can travel to a specific point in the past or future and spend as much time there as you need to have a cup of coffee. One of the four stories in the work is about a married couple. The man, when he learns that he has Alzheimer's, writes a letter to his wife, who, when she becomes aware of the letter, travels back in time to ask her husband for it. The trip gives them an opportunity to talk about the diagnosis and its effect on them, a discussion that did not happen at the time. Moreover, in the letter, the man describes what kind of treatment he wants in the future. This letter is no more positive than Alice's: "You are a nurse, so I assume you have noticed by now that I have an illness that causes forgetfulness. I imagine that in parallel with the loss of my memory, you will put aside your personal feelings and take care of me with the indifference of a nurse. [...] You don't have to stay by my side as a nurse either. I'm a useless husband, leave me! [...] I do not want you to remain my wife out of pity." (Kawaguchi, 2019, 126). However, Kohtake, the wife does not feel caring for Fusagi a burden, on the contrary, she thinks it is the best solution.

These stories shed light on the fact that, having a diagnosis, the characters can control what happens to them later, according to their habitus. They both find themselves worthless without their memories and would free their loved ones from the burden of caring. At the same time, both stories show that their family does not see this as such, they consider them valuable, lovable even in the late stages of the disease, and they are convinced that the essence of the loved one's individuality has been preserved. This message is, on the one hand, humane and hopeful, and, on the other hand, highlights that one of the main solutions of the law does not coincide with the moral guidelines that emerge from the stories. The essence of a preliminary legal declaration is that the will of the patient can be enforced even if she is no longer able to express it. If family members override this out of love, it is a paternalistic solution 
that deprives the individual of her dignity. These briefly presented narratives highlight that a system based on preliminary legal declarations can lead to inhuman results as characters encourage euthanasia, abandonment, and voice the worthlessness of their future self - if we do not have widespread knowledge of this symptom, and it is not generally accepted that the life of people with dementia is still precious.

\subsection{Care and substitute decision-making}

In novels about dementia, as the condition of patients deteriorates, it naturally occurs that family members begin to care for them. Later, when this is no longer enough or becomes too difficult, a qualified nurse is often admitted, and the patient is eventually placed in an institution. It is especially characteristic that the patient's decisionmaking right is not mentioned in connection with these steps. I have previously quoted an excerpt from Enger's work, about the placement of the narrator's mother in an institution. In the novel, the children look for a solution, their mother is not in a decision-making position. In an interview from the previously mentioned research, a father who is the guardian of his adult son who is mentally ill, described guardianship as not helpful, "a bureaucratic hurdle".

A similar picture emerges from the fictional stories and narrative life story interviews recorded in the research: the legal framework for substitute decisionmaking is very far from the ordinary realities of those involved. It is described as only natural that the individual, while able to do so, decides on issues that are important to her, just as when she is no longer able to do so, the right to decide (described rather as a heavy responsibility in narratives) slips into the hands of family members. In this case, the literature seems to bowdlerize, since substitute decision-making is an institution that exists in every legal system and is not free of conflicts, but these conflicts do not appear in the examined narratives. Not a literary work, but noteworthy is the movie I Care a Lot, which is about the potential of abuse in substitute decisionmaking. It is important to note that in the movie, a professional legal guardian tries to drain the savings of her elderly wards, so it is not about relationships between family members. Opportunities for abuse within the family seem to be taboo in this round.

\section{SUMMARY}

I hope that even if this short study raises many further questions, it sheds light on the extensive literature on Alzheimer's disease, and on the valuable empirical material they provide for understanding the contradictions between law and social reality. I also consider an important lesson that, at the same time, it would be wrong to set the picture described by literary works as a standard. The stories examined often reflect uncontrolled everyday biases, such as the idea of the worthlessness of the lives of patients with dementia, the fear of those involved, and the idealization of the love of family members and the uncritical acceptance of the resulting paternalism. At the same time, if we can believe the picture emerging from literary narratives and our research results so far, legal institutions are completely foreign, irrelevant, and meaningless to those concerned, the law in this field is so detached from the social reality that it is not able regulate it. a healthy strain between black-letter law and 
social reality is the key to effective legal regulation, which would be much needed to preserve the dignity of those involved - potentially all of us.

\section{ACKNOWLEDGEMENTS}

The paper is related to the research led by Prof. István Hoffman, entitled Restriction of the legal capacity of adults in Hungary, supported by NKFIH (FK 132513).

\section{References}

Bayley, J. (1999). Elegy for Iris. New York: Picador, MacMillan

Bernlef, J. (1984). Hersenschimmen. Amsterdam: Querido [J. Bernlef (1989). Out of Mind. London: Faber and Faber; J. Bernlef (2008). Agyrémek (ford.: Wekerle Sz.). Budapest: Gondolat]

Block, S. M. (2014). A place beyond words: The literature of Alzheimer's. New Yorker. https:// www.newyorker.com/books/page-turner/place-beyond-words-literature-alzheimers [Accessed: 31. 08. 2021.]

Cabré, J. (2011). Jo confesso. Barcelona: Proa [J. Cabré (2014). Én vétkem (ford.: Tomcsányi Zs.). Budapest: Jelenkor.]

DeBaggio, T. (2002). Losing My Mind. An Intimate Look at Life with Alzheimer's. New York: The Free Press, Simon \& Schuster.

Delgado, R. (1989). Storytelling for Oppositionists and Others: a Plea for Narrative. Michigan Law Review, 8, 2411-2441. https://doi.org/10.2307/1289308

Enger, C. (2013). Mors gaver. Copenhagen: Gylendal. [C. Enger (2013). Anyám ajándékai (ford.: Petrikovics E.). Budapest: Typotex.]

Franzen, J. (2001). The Corrections. New York: Picador, MacMillan. [J. Franzen (2012). Javítások (ford.: Bart I.) Budapest: Európa.]

Genova, L. (2007). Still Alice. iUniverse. [L. Genova (2007). Megmaradt Alice-nek (ford.: Neset A.). Szeged: Könyvmolyképző.]

Harvey, S. (2010). The Wilderness. London: Vintage

H. Szilágyi I. (2010). Jog és irodalom (habilitációs előadás). Iustum Aequum Salutare, 6(1), 5-27.

Keaton, D. (2011). Then Again. New York: Random House. [D. Keaton (2012). Játszd újra, Diane! (ford.: Béresi Cs.). Budapest: Kossuth.]

Márquez, G. G. (2012). One Hundred Years of Solitude. London: Penguin Books.

Nagy T. (2015). „S ő levelemre városunkba jön”, avagy hány életük van a jog és irodalom kutatásoknak? In Fleck Z. \& Fekete B. (eds). Tanulmányok a kortárs jogelméletröl (pp. 115-168). Budapest: Eötvös Kiadó.

Shenk, D. (2003). The Forgetting. Understanding Alzheimer's: a Biography of a Disease. London: William Collins

Simpson, J. R. (2014). DSSM-5 and Neurocognitive Disorders. Journal of the American Academy of Psychiatry and the Law, 42(2), 159-164.

Thomas, M. (2014). We Are Not Ourselves. New York: Simon \& Schuster. [M. Thomas (2017). Nem vagyunk magunk (ford.: Szécsi N.). Budapest: Libri.]

Toshikazu, K. (2019). Before the Coffee Gets Cold. New York: Picador, MacMillan [K. Tosikadzu (2018). Mielőtt a kávé kihül (ford.: Béresi Csilla). Budapest: Kossuth.]Vajda N. (2020). Demencia Magyarországon. a 21. század egyik legnagyobb társadalmi kihívása. Szellem és tudomány. 11(1), 688-689. https://www.uni-miskolc.hu/ btmtt/almanach/687-696. pdf [Accessed: 31. 08. 2021.] 